\title{
Pemanfaatan Limbah Kotoran Puyuh untuk Bahan Dasar Briket sebagai Bahan Bakar Alternatif
}

\author{
(Utilization of Quail Waste for Briquette Production as Alternative Fuels) \\ Wahyu Utami, Suhardi, Zakaria Husein Abdurrahman* \\ Program Studi Peternakan, Fakultas Peternakan, Universitas Boyolali \\ Jl. Pandanaran No.405 Boyolali 57315 \\ Penulis Korespondensi : zhabdurrahman@gmail.com
}

\begin{abstract}
ABSTRAK
Tujuan penelitian ini adalah untuk untuk mengetahui perbandingan terbaik pada bahan penyusun briket dari kotoran puyuh dan sekam dengan tambahan perekat sebagai bahan bakar alternatif. Materi yang digunakan adalah briket yang dibuat dengan 3 perlakuan dan 6 kali ulangan. Dalam penelitian ini terdapat 3 perlakuan, dengan bahan kotoran puyuh dan sekam dengan perbandingan 1:1 (P1), 2:1 (P2), dan 3:1 (P3). Parameter yang diteliti yaitu kadar air, kadar abu, lama bakar briket sampai menjadi abu, dan lama untuk mendidihkan $250 \mathrm{ml}$ air. Penelitian ini menggunakan rancangan acak lengkap (RAL) dengan tiga perlakuan dan enam kali ulangan. Masing-masing ulangan terdiri dari 6 briket. Hasil penelitian menunjukan bahwa kadar air dan kadar abu menunjukkan pengaruh yang nyata, dengan kadar air tertinggi pada P1 sebesar 44,83\% dan terendah pada P3 sebesar 38,38\%. Kadar abu tertinggi pada P1 sebesar $31,57 \%$ dan terendah pada $\mathrm{P} 3$ sebesar $26,74 \%$. Lama nyala briket sampai menjadi abu dan lama untuk mendidihkan air pada hasil penelitian ini menunjukkan pengaruh yang tidak nyata. Kesimpulan dari penelitian ini adalah perbandingan sekam dan kotoran puyuh menghasilkan briket terbaik pada perlakuan perbandingan kotoran puyuh : sekam sebesar 22,5 g : 7,5 g karena menunjukkan kadar air dan kadar abu terendah.
\end{abstract}

Kata Kunci: Kotoran Puyuh, Briket, Bahan Bakar Alternatif

\section{ABSTRACT}

This study aims to determine the best comparison of the briquette production material from quail and husk manure with the addition of adhesives as an alternative energy source. The material used was briquettes which were made with 3 treatments and 6 replications. In this study there were 3 treatments, with quail and husk manure materials in a ratio of $1: 1$ (P1), 2: 1 (P2), and 3: 1 (P3). The parameters studied were water content, ash content, briquette burn duration to ash, and duration time to boil $250 \mathrm{ml}$ of water. This study used a completely 
randomized design (CRD) with three treatments and six replications. The results showed that the water content and ash content showed a significant effect, with the highest water content at P1 of $44.83 \%$ and the lowest at P3 of $38.38 \%$. The highest ash content in P1 was $31.57 \%$ and the lowest in P3 was $26.74 \%$. The duration of the briquette's flame to ash and the time to boil water in the results of this study showed no significant effect. The conclusion of this study showed the best comparison of quail waste and husk ratio was at $22.5 \mathrm{~g}: 7.5 \mathrm{~g}$ because it shows the lowest water content and ash content.

Keywords: Quail Dirt, Briquettes, Alternative Fuels

\section{PENDAHULUAN}

Usaha peternakan mempunyai prospek untuk dikembangkan karena tingginya permintaan akan produk pangan hewani. Usaha yang diminati saat ini adalah ternak puyuh karena pemeliharaannya cukup mudah, tidak membutuhkan kandang, dan lahan yang luas. Penanganan limbah kotoran puyuh di sekitar perumahan warga belum menjadi perhatian, limbah hanya dibiarkan di belakang kandang dan menganggu warga. Limbah kotoran puyuh dianggap lebih menyengat baunya dibanding kotoran sapi. Pemanfaatan kotoran puyuh sebagai bahan baku dalam pembuatan briket merupakan salah satu bahan bakar alternatif yang tepat. Tujuan pembuatan briket dari limbah kotoran puyuh juga untuk mendayagunakan dan meningkatkan nilai ekonomis dari limbah kotoran puyuh. Selain limbah kotoran puyuh, sekam padi jumlahnya juga berlimpah, sehingga berpotensi dijadikan sebagai campuran briket kotoran puyuh,

Limbah kotoran puyuh, sekam, perekat, dan air, dapat menjadi bahan bakar alternatif yang mempunyai nilai jual yang tinggi. Bahan utama yang harus terdapat di dalam bahan baku adalah selulosa, semakin tinggi kandungan selulosa maka kualitas briket semakin baik. Briket yang mengandung zat terbang yang terlalu tinggi cenderung mengeluarkan asap dan bau tidak sedap. Oleh karena itu perlu dilakukan penelitian mengenai pemanfaaan limbah kotoran puyuh sebagai briket.

Tujuan penelitian ini adalah untuk untuk mengetahui perbandingan terbaik pada bahan penyusun briket dari kotoran puyuh dan sekam dengan tambahan perekat sebagai bahan bakar alternatif.

\section{MATERI DAN METODE}

Penelitian ini dilaksanakan di Laboratorium Terpadu Universitas Boyolali. Pengujian kadar air dilaksanakan di Laboratorium Balai Pelayanan dan Kesehatan Masyarakat Veteriner, Boyolali. Pengujian kadar abu dilaksanakan di Laboratorium Ilmu Nutrisi dan Pakan Universitas Diponegoro. Lama nyala dan lama untuk mendidihkan air dilaksanakan di Laboratorium Terpadu Universitas Boyolali.

Bahan yang digunakan dalam penelitian ini adalah limbah kotoran puyuh, sekam, dan perekat. Limbah kotoran puyuh diambil dari ternak puyuh di Desa Jemowo yang berumur 3 bulan dengan populasi 100 ekor. Sekam didapat dari penggilingan padi yang berada di Jatinom, Klaten. Perekat yang digunakan didapat dari tapioka yang beredar di pasaran.

Peralatan yang digunakan dalam 
penelitian ini adalah drum dan cerobong asap untuk karbonasi sekam, ember, timbangan digital, seng, ayakan, bambu untuk mencetak adonan, dan alat press. Rancangan yang digunakan dalam penelitian ini adalah rancangan acak lengkap pola searah dengan tiga perlakuan dan enam kali ulangan. Masing-masing ulangan terdiri dari enam briket. Perlakuan dala penelitian ini terdiri dari: $\mathrm{P} 1$ = perlakuan dengan perbandingan kotoran puyuh:sekam $=1: 1+30 \mathrm{~g}$ tapioka. $\mathrm{P} 2$ $=$ perlakuan dengan perbandingan kotoran puyuh:sekam $=2: 1+30 \mathrm{~g}$ tapioka. $\mathrm{P} 3=$ perlakuan dengan perbandingan kotoran puyuh:sekam $=3: 1+30 \mathrm{~g}$ tapioka.

\section{HASIL DAN PEMBAHASAN}

Data kadar air, kadar abu, lama nyala briket sampai menjadi abu, dan lama mendidihkan air $250 \mathrm{ml}$ tersaji pada Tabel 1.

Tabel 1. kadar air, kadar abu, lama nyala briket sampai menjadi abu, lama mendidihkan air $250 \mathrm{ml}$

\begin{tabular}{ccc}
\hline Perlakuan & Kadar air (\%) & Kadar abu (\%) \\
\hline P1 & $44,83^{\mathrm{ab}}$ & $31,57^{\mathrm{a}}$ \\
P2 & $46,28^{\mathrm{a}}$ & $28,56^{\mathrm{ab}}$ \\
P3 & $38,38^{\mathrm{b}}$ & $26,74^{\mathrm{b}}$ \\
\hline Jumlah & 129,49 & 86,88 \\
\hline Keterangan: & a,b,c & superskrip yang berbeda pada \\
kolom yang sama menunjukkan perbedaan yang \\
nyata (P<0,05). P1 = perbandingan kotoran puyuh \\
dan sekam 1:1, P2 = perbandingan kotoran puyuh \\
dan sekam 2:1, P3 = perbandingan kotoran puyuh \\
dan sekam 3:1.
\end{tabular}

Kotoran sapi mengandung lignin, seluosa, dan hemiselulosa yang berasal dari bahan pakan hijauan ternak, yang mengakibatkan briket yang dihasilkan mengandung kadar air lebih tinggi dibandingkan briket berbahan dasar kotoran puyuh, karena bahan-bahan tersebut tidak ada. Menurut Windyasmara et al. (2012) kotoran sapi masih mengandung selulosa yang cukup tinggi. Hal ini sejalan dengan
Santosa et al. (2010) bahwa briket yang dibuat dari bahan baku dengan campuran kotoran sapi yang banyak akan menyebabkan kandungan air tinggi, karena memiliki jumlah pori-pori yang banyak dan mengandung selulosa, lignin, dan hemiselulosa. Pada hasil penelitian ini semakin banyak kotoran puyuh maka kadar air semakin rendah. Hal ini didukung oleh Hutauruk et al. (2015) yang menyatakan bahwa kadar air yang tinggi diduga disebabkan pori-pori masih cukup banyak dan mampu menyerap air.

Faktor yang menyebabkan lama nyala briket tidak berpengaruh nyata adalah bahan yang digunakan dalam pembuatan briket memiliki ukuran partikel yang hampir sama. Selain itu kandungan karbon (C) dalam kotoran puyuh juga memiliki pengaruh terhadap nyala briket. Semakin banyak kadar C dalam briket, maka semakin tinggi pula kalor pembakaran. Menurut Luthfianto et al. (2012) kandungan rasio $\mathrm{C} / \mathrm{N}$ dalam kotoran unggas sekitar 17,71 serta kandungan rasio C/N pada sekam sekitar 67. Menurut

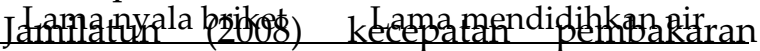

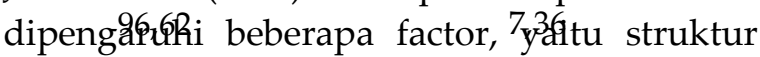
bahan, 95 a 7 fdungan karbon terikat, dan tingkat kepada 9523 bahan $\quad 7,37$

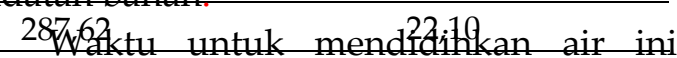
berhubungan dengan lama nyala briket dimana lama nyala pada briket semakin rendah sehingga waktu yang dibutuhkan untuk mendidihkan air semakin lama. Menurut Langkai et at. (2015) semakin lama waktu pembakaran maka semakin lama pula waktu yang dibutuhkan untuk mendidihkan 1 liter air. Menurut Balong et al. (2016) nilai kalor menjadi parameter mutu yang paling penting bagi briket arang sebagai bahan bakar, sehingga nilai kalor sangat menentukan kualitas briket arang. Apabila nilai kalor bakar arang semakin tinggi, maka akan semakin baik pula kualitas briket arang yang dihasilkan. Waktu untuk mendidihkan air ini tidak berpengaruh nyata karena bahan- 
bahan untuk pembuatan memiliki ukuran yang sama, seperti halnya pada lama nyala briket.

Sekam yang sudah dikarbonasi memiliki kadar silikat $87-97 \%$. Kadar silika yang tinggi dapat menyebabkan kadar abu tinggi. Menurut pendapat Karim et al. (2014) semakin tinggi kadar abu pada briket berpengaruh pada laju pembakaran yang disebabkan rendahnya transfer panas ke bagian dalam briket dan difusi oksigen ke permukaan briket arang selama proses pembakaran serta tingginya kadar abu dapat menghasilkan emisi debu yang menyebabkan polusi udara dan mempengaruhi volume pembakarannya.

Hasil analisis harga briket $/ \mathrm{kg}$ tertera pada tabel 2 yang menunjukkan biaya pembuatan briket pada masing-masing perlakuan.

Tabel 2. Biaya Pembuatan Briket Kotoran Puyuh

\begin{tabular}{cc}
\hline Perlakuan & Harga/kg \\
\hline P1 & Rp 4.375 \\
P2 & Rp 4.416 \\
P3 & Rp 4.437 \\
\hline
\end{tabular}

Keterangan: $\mathrm{P} 1$ = perbandingan kotoran puyuh dan sekam 1:1, P2 = perbandingan kotoran puyuh dan sekam 2:1, P3 = perbandingan kotoran puyuh dan sekam 3:1.

\section{KESIMPULAN}

Kesimpulan dari penelitian ini adalah perbandingan sekam dan kotoran puyuh menghasilkan briket terbaik pada perlakuan perbandingan kotoran puyuh:sekam sebesar 22,5 g : 7,5 g karena menunjukkan kadar air dan kadar abu paling rendah.

\section{DAFTAR PUSTAKA}

Balong, S., I. Isa, dan H. Iyabu Karakterisasi Biobriket dari Eceng Gondok (eichornia crassipes) Sebagai Bahan Bakar
Alternatif. Jurnal Entropi. 11(2):147152.

Hutauruk, N. B., B. Zaman, dan Syafrudin. 2015. Pembuatan Briket dari Bottom Ash dan Arang Sekam Padi sebagai Sumber Energi Alternatif (Studi Kasus: Industri tekstil $\mathrm{X}$, Ungaran-Semarang). Jurnal Teknik Lingkungan. 4(2):1-9.

Jamilatun, S. 2008. Sifat-Sifat Penyalaan dan Pembakaran Briket Biomassa, Briket Batubara dan Arang Kayu. Jurnal Rekayasa Proses. 2(2):37-40.

Karim, M. A., E. Ariyanto, dan A. Firmansyah. 2014. Biobriket Enceng Gondok (Eichhornia crassipes) sebagai Bahan Bakar Energi Terbarukan. Reaktor. 15(1):59-63.

Langkai, R. P., F. Pangkerego, dan H. F. Pinatik. 2015. Kajian Pembuatan Briket Bioarang dari Limbah Kulit Durian dengan Kombinasi Serutan Kayu dan Tempurung Kelapa. Cocos. 6(16):1-9.

Luthfianto, D., Mahajoeno, E., dan Sunarto. 2012. Pengaruh Macam Limbah Organik dan Pengenceran Terhadap Produksi Biogas dari Bahan Biomassa Limbah Peternakan Ayam. Bioteknologi. 9(1):18-25.

Santosa, R. Mislaini, dan S. P. Anugrah. 2010. Studi Variasi Komposisi Bahan Penyusun Briket Dari Kotoran Sapi dan Limbah Pertanian. http://www.opi.lipi.go.id/data/1228964 432/data/13086710321319787133.makal ah.pdf.

Windyasmara, L., A. Pratiwiningrum, dan L. M. Yusiati. 2012. Pengaruh Jenis Kotoran Ternak sebagai Substrat dengan Penambahan Serasah Daun Jati (Tectona grandis) Terhadap Karakteristik Biogas pada Proses Fermentasi. Buletin Peternakan. 36(1):40-47. 